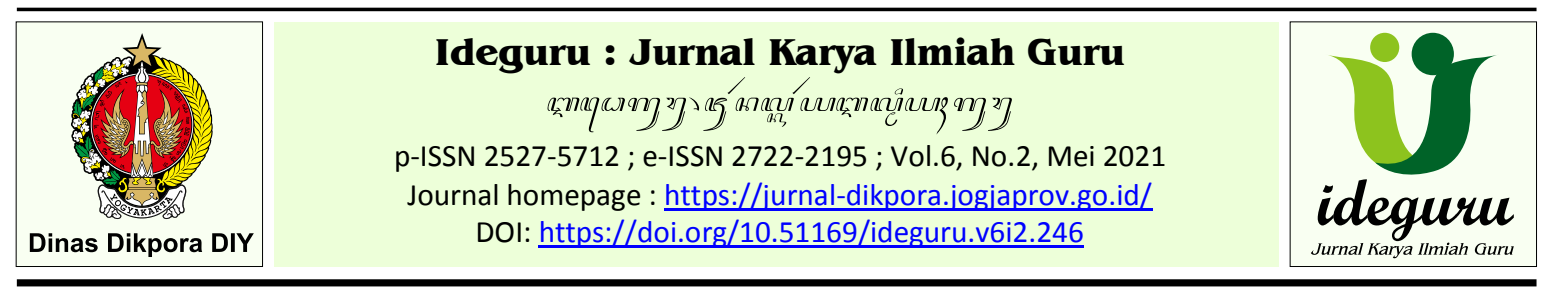

Artikel Penelitian - Naskah dikirim: 26/02/2021 - Selesai revisi: 26/04/2021 - Disetujui: 28/04/2021 - Diterbitkan: 01/05/2021

\title{
Penerapan Model Think Pair Share dalam Meningkatkan Motivasi, Aktivitas dan Prestasi Belajar Bahasa Arab
}

\author{
Sri Suharti \\ MTs Negeri 1 Bantul \\ srihartimurti1@gmail.com
}

\begin{abstract}
Abstrak: Mayoritas peserta didik beranggapan bahwa Bahasa Arab merupakan pelajaran paling sulit. 89,25\% dari peserta didik kelas VII F tahun pelajaran 2019/2020 di MTs Negeri 1 Bantul belum pernah belajar Bahasa Arab, dan ini menyebabkan peserta didik tidak memiliki motivasi dan aktivitas yang tinggi dalam mempelajari Bahasa Arab. Tujuan penelitian ini untuk meningkatkan motivasi, aktivitas dan prestasi belajar Bahasa Arab. Pada studi prasiklus, peserta didik yang mencapai Kriteria Ketuntasan Minimal (KKM) sebanyak dua orang dan nilai rata-rata 41,25. Penelitian ini dilakukan untuk meningkatkan proses pembelajaran Bahasa Arab melalui penerapan Think Pair Share (TPS). Model pembelajaran TPS menekankan peningkatan motivasi dan aktivitas belajar dengan cara berdiskusi, berbagi informasi dengan classmate dan berinteraksi dengan sumber belajar. Penelitian ini menggunakan model Coast Classroom Action Research dengan dua siklus dan setiap siklus terdiri dari dua pertemuan dan satu kali tes siklus. Data motivasi dan aktivitas belajar diperoleh dari observasi setiap pertemuan. Penelitian ini memperoleh hasil bahwa TPS mampu meningkatkan nilai rata-rata 41,25 pada prasiklus meningkat 69,74 pada siklus ke-1, dan meningkat 73,34 pada siklus ke-2. TPS juga meningkatkan jumlah ketuntasan mencapai KKM 70 pada prasiklus $2(6,25 \%)$ meningkat 14 (43,75\%) pada siklus ke-1, dan 19 (59,37\%) pada siklus ke-2.
\end{abstract}

Kata Kunci: Think Pair Share, motivasi, aktivitas, prestasi

\section{Implementation of Think Pair Share Model to Improve Motivatian, Activity and Achievement in Arabic}

\begin{abstract}
Most of students assume that Arabic the most difficult lesson. 89,25\% of students VII F class at school year 2019/2020 of MTs Negeri 1 Bantul have never learned it. This factor makes students haven't high motivation and more activities and unable to master Arabic very wall, and this reseach aims to improve it. In pre cycle the student's achievement everage score 41,25 and who passed the minimum mastery criteria two students. This research was cunducted in order to make a better condition of teaching and learning Arabic through the implementatioan of Think Pair Share (TPS) model. The basic foundation of this model was to make students have high motivation and more activities in teaching and learning process by discussing with their classmate. They can to interact with source of learning, they can take and give some information from their classmate. This research applied Coast Classroom Research Action with two cycle. The motivation and activity data gathered from the end of teaching and learning process, and the achievement student gathered from the end of each cycle test. This research was found that improvement of everage score for each cycle, from 41,25 in pre cycle to 69,74 in first cycle, from 69,74 in first cycle to 73,23 in second cycle. It also was found the member of students who passed KKM for each cycle, from $2(6,25 \%)$ in pre cycle to $14(43,75 \%)$ in first cycle, from 14 in first cycle to $19(59,37 \%)$ in second cycle.
\end{abstract}

Keyword: Think Pair Share, motivation, activity, achievement

\section{Pendahuluan}

Dalam kurikulum 2013, Bahasa Arab merupakan mata pelajaran bahasa asing yang wajib diberikan di MTs Negeri 1 Bantul. Penilaian mata pelajaran Bahasa Arab mencakup aspek sikap, pengetahuan dan keterampilan (Permendikbud Nomor 23 Tahun 2016). Dalam peraturan akademik Kurikulum Tingkat Satuan Pendidikan (KTSP) MTs Negeri 1 Bantul dijelaskan bahwa peeserta didik dinyatakan tuntas jika mendapatkan nilai minimal Baik dalam sikap dan menuntaskan kompetensi pengetahuan serta kompetensi keterampilan (Peraturan Akademik MTs Negeri 1 Bantul Tahun Pelajaran 2019/2020). Peserta didik dinyatakan tuntas jika mencapai KKM 70 (KKM MTs Negeri 1 Bantul Tahun Pelajaran 2019/2020). 
Peserta didik kelas VII $\mathrm{F}$ tahun pelajaran 2019/2020 semester I berjumlah 32 terdiri dari 18 laki-laki dan 14 perempuan. Peserta didik yang pernah belajar Bahasa Arab sebanyak 6 $(18,75 \%)$ sedangkan $26(89,25 \%)$ belum pernah. Hasil penilaian harian tertulis ke-2 yang dilaksanakan pada Selasa 15 Oktober 2019 pada KD 3.2. Materi kalam tentang al Marofiiqu al Madrosiyyah dan KD 4.5. Materi insyak tentang al Marofiiqu al Madrosiyyah peserta didik yang mencapai KKM sebanyak $2(6,25 \%)$ sedangkan $30(93,75 \%)$ belum tuntas. Rendahnya prestasi Bahasa Arab diduga input dan motivasi belajar rendah, serta guru masih menggunakan model pembelajaran konvensional. Dalam model konvensioanal, guru menjadi satu-satunya sumber belajar, hal ini menyebabkan peserta didik kurang berintaraksi dengan classmate dan sumber belajar. Model pembelajaran konvensional lebih banyak menggunakan belahan otak kiri, sementara belahan otak kanan kurang diperhatikan (Mahmudah dan Wahab, 2008: 68). Proses berpikir otak kiri bersifat logis, sekuensial, linear, dan rasional (Porter dan Hernancki, 2008: 36). Oleh karena itu, pembelajaran membosankan dan aktivitas belajar rendah. Upaya untuk mengatasi masalah tersebut, guru menerapkan model TPS. Guru dalam fungsinya sebagai pengelola pembelajaran menciptakan situasi dan kondisi sabaik-baiknya (Syah, 2011: 249-250). Salah satu tugas guru sebagai perencana pembelajaran memilih metode yang tepat bagi peserta didik dan mampu menerapkannya (Iskandarwassid dan Suhendar, 2008: 159).

TPS merupakan salah satu strategi pembelajaraan cooperative learning. Dalam pembelajaran cooperative, peserta didik diharapkan saling membantu, saling berdiskusi, dan saling mambangun pengetahuan (Slavin, 2015: 4). Menurut Bennet dalam Isjoni, pembelajaran cooperative learning guru harus menerapkan lima unsur yaitu; pertama positive interdepedance saling menumbuhkan perasaan dalam jiwa peserta didik bahwa dirinya terintegrasi dalam kelompoknya, kedua interaction face to face semua anggota kelompok diberi kesempatan bertatap muka dan berdiskusi, ketiga tanggung jawab pribadi setiap peserta didik memiliki tanggung jawab pribadi untuk menguasai materi pembelajaran, keempat komunikasi atar anggota setiap peserta didik dituntut mampu bekerjasama dengan kelompoknya dalam memecahkan masalah, kelima pemerosesan kelompok peserta didik diberi tugas untuk mengevalusi bagaimana mereka bekerjasama, saling berkomunikasi, saling melengkapi, saling terkait dalam kelompoknya (Isjoni, 2011: 60). Diantara keunggulan TPS mampu meningkatkan partisipasi, memberikan kesempatan berkontribusi kepada setiap kelompok, interaksi antar pasangan lebih mudah, dan pembentukan kelompok juga lebih mudah sehingga tidak menyita waktu (Lie, 2008: 86).

Melalui penerapan TPS diharapkan motivasi, aktivitas dan prestasi belajar meningkat. Dari penelusuran penelitian terdahulu TPS mampu meningkatkan motivasi belajar bahasa asing. Pertama Penerapan Model Pembelajaran Kooperatif Tipe Think Pair Share Untuk Meningkatkan Kemampuan Menghafal Mufrodat Bahasa Arab Pada Siswa Kelas III di Madrasah Ibtidaiyah Islamiyah Kota Malang menemukan hasil bahwa ketuntasan belajar Bahasa Arab 69\% pada prasiklus, meningkat $73 \%$ pada siklus pertama, meningkat $100 \%$ pada siklus kedua (Rochimah, Hanif, dan Dina, 2019). Kedua The Implementation of Think-Pair-Share Model to Improve Students' Ability in Reading Narrative Texts menemukan hasil jumlah ketuntasan pembelajaran membaca teks naratif Bahasa Inggris 55\% pada prasiklus, meningkat $65 \%$ pada siklus pertama, dan meningkat $82 \%$ pada siklus kedua (Sugiarto dan Sumarsono: 2014). Ketiga Penerapan Metode Pembelajaran Think Pair Share (TPS) untuk meningkatkan kemampuan menulis Bahasa Arab Siswa-Siswi MTs Satu Atap Al - Hidayah Batu menemukan hasil skor rata-rata menulis Bahasa Arab 49,08 pada prasiklus, meningkat 71,12 pada siklus pertama, dan meningkat 77,29 pada siklus kedua (Lestari: 2019). Keempat Improving Writing Skills; an Implementation of "Think Pair Share" For Islamic Junior Schools Students menemukan hasil skor rata-rata keterampilan menulis Bahasa Inggris 56,8 pada prasiklus, meningkat 78,7 pada siklus pertama, meningkat 73,69 pada siklus kedua (Suhrowardi, 2020).

Berdasarkan latar belakang masalah tersebut di atas, penulis merumuskan masalah sebagai berikut; bagaimana penerapan model Think Pair Share (TPS) dalam meningkatkan motivasi belajar, aktivitas belajar, dan prestasi belajar Bahasa Arab? Tujuan penelitian ini untuk mengetahui penerapan TPS dalam pembelajaran Bahasa Arab, dalam meningkatkan motivasi belajar peserta didik, aktivitas belajar peserta didik, dan prestasi belajar Bahasa Arab. Manfaat penelitian bagi peserta didik agar mampu meningkatkan motivasi dan aktivitas serta prestasi belajar Bahasa Arab, dan bagi guru agar dapat meningkatkan kualitas proses pembelajaran Bahasa Arab. 


\section{Metode Penelitian}

Jenis penelitian ini Penelitian Tindakan Kelas (PTK). Subyek penelitian peserta didik kelas VII F di MTs Negeri 1 Bantul pada Tahun Pelajaran 2019/2020 semester I berjumlah 32 terdiri dari 18 laki-laki dan 14 perempuan serta satu orang guru Bahasa Arab. Objek penelitian peserta didik mencakup hasil pengamatan motivasi dan aktivitas belajar, hasil tes siklus ke1 dan siklus ke-2. Objek penelitian guru penerapan sintak model TPS dalam proses pembelajaran. Waktu penelitian dari awal September sampai akhir November 2019.

Metode pengumpulan data menggunakan observasi, tes tertulis, dan wawancara bebas. Data penelitian peserta didik diperoleh melalui instrumen check list motivasi belajar, check list aktivitas belajar menggunakan skala Guttman dengan rentang $0-1$, hasil tes siklus ke- 1 dan siklus ke-2, serta wawancara bebas. Data penelitian guru pada penerapan model TPS diperoleh melalui instrumen check list menggunakan skala rating scale dengan rentang 1-3, catatan harian selama PBM, hasil refleksi setelah PBM. Data hasil observasi diolah menggunakan penilaian acuan kriteria dengan skala 0-100 (Widoyoko, 2014: 255). Dalam menentukan kriteria digunakan rumus kurva normal skala lima seperti pada tabel 1 berikut (Sudijono, 2008: 329).

Tabel 1. Penentuan Kriteria Penilaian

\begin{tabular}{lc}
\hline \multicolumn{1}{c}{ Kurva Normal } & Kriteria \\
\hline Mean Siklus ke-1 + 1,5 SD & A \\
Mean Siklus ke-1 + 0,5 SD & B \\
Mean Siklus ke-1 - 0,5 SD & C \\
Mean Siklus ke-1 - 1,5 SD & D \\
Di bawah Mean Siklus ke-1 -1,5 SD & E \\
\hline
\end{tabular}

(Mean: Rata-rata Nilai, SD: Standar Deviasi)

Sebagai acuan membuat kriteria penulis menentukan dari data siklus ke-1. Data prestasi belajar Bahasa Arab diolah dengan penilaian acuan kreteria dengan skala 0-100, kemudian dibuat kriteria dengan KKM. Peserta didik yang mencapai KKM masuk dalam kriteria Tuntas, dan sebaliknya peserta didik yang tidak mancapai KKM masuk kriteria Tidak Tuntas.

PTK dimaksudkan untuk memperbaiki dan meningkatkan kualitas proses pembelajaran serta hasil belajar (Suyitno, 2018: 1). PTK ini menggunakan model Coast. Prosedur penelitian terdiri dari empat tahap yaitu; Pertama perencanaan. Kegiatan perencanaan meliputi menyusun RPP, membuat Power Point, membuat media pembelajaran berupa gambar-gambar, menyusun check list motivasi dan aktivitas belajar, menyusun rating scale penerapan PBM model TPS, menyusun hand out pembelajaran, menyusun LKS, menyusun perangkat soal tes siklus ke-1 dan siklus ke-2, dan membuat lembar catatan harian. Kedua tindakan. Kegiatan tindakan guru menerapkan model TPS meliputi kegiatan awal, kegiatan inti dan kegiatan akhir yang tertuang dalam RPP. Ketiga pengamatan. Kegiatan pengamatan proses mengumpulkan data selama PBM berlangsung dengan cara menyontreng rating scale penerapan PBM model TPS, menyontreng lembar observasi motivasi dan aktivitas belajar, dan menulis lembar catatan harian. Keempat refleksi guru dan observer berdiskusi hasil pengamatan yang diperoleh selama PBM. Hasil refleksi ini digunakan untuk mengukur tingkat keberhasilan penerapan model TPS dan sebagai dasar untuk melakukan tindakan pada pertemuan berikutnya (Sugiyono, 2015: 47-48).

Setiap tahap terdiri dari dua siklus dan setiap siklus terdiri tiga kali pertemuan. Siklus ke1 terdiri dari pertemuan ke-1 PMB KD 3.1. Materi istimak tentang al Adawatu al Madrosiyyah, pertemuan ke-2 PBM KD 4.1. Materi kalam tentang al Adawatu al Madrosiyyah dan peretemuan ke-3 tes siklus ke-1. Siklus ke-2 terdiri dari pertemuan ke-1 PMB KD 3.3. Materi al Tarkib tentang al Adawatu al Madrosiyyah pertemuan ke-2 PBM KD 4.4. Materi al Qira'ah tentang al Adawatu al Madrosiyyah dan peretemuan ke-3 tes siklus ke-2.

Sintak penerapan TPS ada tiga yaitu; Pertama thinking guru memberikan stimulus berupa pertanyaan-pertanyaan tentang materi pembelajaran dan memberikan kesempatan peserta didik berpikir melalui proses diskusi, kedua pairing peserta didik berdiskusi, saling memberi informasi dengan classmate dalam rangka memecahkan masalah, ketiga sharing peserta didik mengkomunikasikan hasil diskusi di depan kelas (Suprijono, 2012: 91).

Indikator variabel penerapan model TPS sebanyak dua belas terdapat dalam RPP. Kegiatan awal mencakup salam pembuka lalu menyiapkan peserta didik secara fisik dan psikhis, melakukan pre test, melakukan appersepsi dan memotivasi, menyampaikan cakupan materi, tujuan serta manfaat pembelajaran. Kegiatan inti mencakup kegiatan pembelajaran sesuai dengan tujuan pembelajaran, mempresentasikan materi pembelajaran dengan cara memberikan pertanyaan-pertanyaan yang menantang dan penting, guru menggunakan contoh yang bervariatif dalam pembelajaran, menginstruksikan peserta didik mempresntasikan hasil diskusi di depan kelas, 
guru memntau aktivitas peserta didik, guru memtau presentasi peserta didik di depan kelas, guru memberikan penguatan verbal dan nonverbal. Ketiga kegiatan akhir terdiri dari post test, pemberian penghargaan kepada siswa yang mendapat nilai tertinggi, meyampaikan rencana pembelajaran pertemuan yang akan datang kemudian salam penutup.

Salah satu tugas guru memberi motivasi kepada peserta didik untuk belajar (Iskandarwassid dan Sunendar, 2008: 156). Motivasi merupakan salah satu syarat belajar. Menurut Mc. Donald (dalam Hamalik, 2008: 158), motivasi merupakan perubahan energi dalam diri seseorang yang ditandai munculnya perasaan dari dalam diri untuk melakukan sesuatu. Menurut Maslow (dalam Slamento, 2003: 170), motivasi adalah kebutuhankebutuhan tertentu yang membangkitkan dan mengarahkan seseorang untuk bertingkah laku.

Jadi, motivasi adalah proses perubahan energi dalam diri seseorang karena ingin mewujudkan kebutuhan berprestasi. Motivasi mencakup empat unsur yaitu; pertama dimulai dari adanya perubahan energi dalam diri peserta didik, kedua ditandai timbulnya perasaan membutuhkan terhadap mata pelajaran Bahasa Arab, ketiga ditandai adanya reaksi positif dalam diri peserta didik, keempat ditandai adanya perubahan tinggah laku nyata.

Dari penjelasan tersebut penulis merumuskan indikator variabel motivasi yang berjumlah sembilan yaitu; peserta didik memulai pelajaran tepat waktu, membawa buku pelajaran Bahasa Arab, mengikuti pembelajaran dengan tertib, tidak mengantuk saat mengikuti pembelajaran, mendengarkan dan memperhatikan penjelasan dari guru, bertanya kepada classmate atau kepada guru, menjawab pertanyaan dari classmate atau dari guru, mengerjakan post test, mengalami peningkatan prestasi. Motivasi yang tinggi akan meningkatkan aktivitas belajar. Manifestasi dari aktivitas belajar beupa kebiasaan, keterampilan, pengamatan, berpikir asosiatif dan daya ingat, berpikir rasional, sikap, apresiasi, dan tingkah laku efektif (Djiwandono, 2008: 116).

Belajar adalah kegiatan jiwa dan raga guna memperoleh peubahan kognitif, psikomotor dan afektif melalui pengalaman dalam berinteraksi dengan lingkunganya (Djamarah, 2011: 13). Demikian juga dalam belajar Bahasa Arab melibatkan aktivitas jiwa, indra dan sosial. Semakin banyak inrda yang terlibat dalam belajar akan semakin intesns aktivita belajar (Asrori, 2012: 19).
Jadi, belajar merupakan aktivitas jiwa, fisik, panca inra dan aktivitas sosial. Dari penjelasan tersebut, penulis merumuskan indikator aktivitas belajar yang berjumlah sebelas yaitu; peserta didik duduk berpasangan dengan classmate, membagi tugas dengan classmate, melaksanakan tugas sesuai dengan tanggung jawabanya, merespon stimulus dari classmate, bertanya jawab dengan classmate, berdiskusi dengan tertib, merespon pertanyaan dari guru, mempraktikkan dialog/bacaan dengan classmate, saling membantu dengan classmate, menulis hasil diskusi, mempresentasikan hasil diskusi di depan kelas. Indikator prestasi belajar Bahasa Arab nilai tes siklus ke-1 dan nilai tes siklus ke-2.

Indikator keberhasilan PTK jika terdapat peningkatan kriteria penerapan model TPS dari siklus ke-1 menuju siklus ke-2 minimal Baik, terdapat peningkatan motivasi belajar kriteria minimal Sedang pada siklus ke-1 menuju siklus ke-2 sebesar $75 \%$, terdapat peningkatan aktivitas belajar peserta didik minimal kriteria Sedang pada siklus ke-1 menuju siklus ke-2 sebesar 75\%, terdapat peningkatan jumlah ketuntasan belajar Bahasa Arab dari prasiklus menuju siklus ke-1 dan siklus ke-2 sebesar 50\%.

\section{Hasil dan Pembahasan}

PTK ini dilakukan untuk meningkatkan kualitas proses pembelajaran. Kualitas proses pembelajaran adalah tingkat keberhasilan penerapan model TPS dalam meningkatkan motivasi dan aktivitas serta prestasi belajar Bahasa Arab. Obyek penelitian penerapan model TPS adalah kegiatan guru. Pada kegiatan awal, guru mengucap salam pembuka, menyiapkan peserta didik secara fisik dan psikhis, melakukan pre test, melakukan appersepsi dan memotivasi, menyampaikan cakupan materi, tujuan serta manfaat pembelajaran.

Pada kegiatan inti guru menginstruksikan peserta didik duduk berpasangan dengan classmate, mempresentasikan materi pembelajaran, guru menginstruksikan peserta didik berdiskusi mencari jawaban kemudian mempresntasikan hasil diskusi di depan kelas, guru memberi penguatan terhadap presentasi peserta didik. Pada kegiatan akhir, guru melakukan post test, pemberian penghargaan kepada siswa yang mendapat nilai tertinggi, meyampaikan rencana pembelajaran pertemuan akan datang, dan diakhiri salam penutup.

Kegiatan pengamatan dilakukan oleh observer dengan menyontreng lembar observasi pada indikator proses pembelajaran dan catatan harian. Hasil pengamatan penerapan model TPS 
dikonversi dengan skala lima dapat dilihat pada tabel 2 berikut.

Tabel 2. Penghitungan Kriteria Penerapan Model

\begin{tabular}{lcc}
\hline \multicolumn{1}{c}{ Penghitungan Konversi } & Rentang & Kriteria \\
\hline $81,96+(1,5 \times 1,96)=85$ & $85 \mathrm{ke}$ & Sangat \\
& atas & Baik \\
$81,96+(0,5 \times 1,96)=83$ & $83-84$ & Baik \\
$81,96-(0,5 \times 1,96)=81$ & $81-82$ & Cukup \\
$81,96-(1,5 \times 1,96)=79$ & $79-80$ & Kurang \\
Di bawah & $78 \mathrm{ke}$ & Sangat \\
$81,96-(1,5 \times 1,96)=79$ & bawah & Kurang \\
\hline
\end{tabular}

Setelah proses pembelajaran selesai, ditemukan hasil bahwa kualitas PBM pada siklus ke-1 sebesar 81,95 masuk kriteria Cukup, dengan nilai 80,56 pada pertemuan ke- 1 dan 83,33 pada pertemuan ke-2, kemudian penulis dan observer melakukan refleksi. Hasil refleksi PBM pertemuan ke-1 ditemukan masalah materi pembelajaran terlalu banyak sehingga tahap presentasi terlaksana dua kelompok. Dari hasil refleksi pada pertemuan ke-1 kemudian guru mengadakan perbaikan mengurangi materi pembelajaran. Hasil refleksi pertemuan ke-2 ditemukan masalah pembagian waktu diskusi dan presentasi tidak seimbang mengakibatkan peserta didik terburu-buru saat mempresentasikan hasil diskusi. Setelah guru memperbaiki kualitas pembelajaran pada siklus ke-1, kualitas PBM pada siklus ke-2 sebesar 96,19 masuk kriteria Sangat Baik, dengan nilai 97,44 pada pertemuan ke-1 dan 94,44 pada pertemuan ke-2. Peningkatan kualitas penerapan TPS dari siklus ke-1 menuju siklus ke-2 dapat dicermati pada tabel 3 .

Tabel 3. Penerapan Model TPS

\begin{tabular}{ccccc}
\hline PBM ke- & $\begin{array}{c}\text { Siklus } \\
\text { Ke-1 }\end{array}$ & Kriteria & $\begin{array}{c}\text { Siklus } \\
\text { Ke-2 }\end{array}$ & Kriteria \\
\hline 1 & 80,56 & C & 97,94 & SB \\
2 & 83,33 & B & 94,44 & SB \\
\hline Rata-rata & 81,95 & C & 96,19 & SB \\
\hline SD & 1,96 & - & 2,47 & - \\
\hline
\end{tabular}

Pada siklus ke-2, hasil refleksi PBM pertemuan ke-1 tidak ditemukan masalah yang segera diselesaikan. Hasil refleksi PBM pertemuan ke-2 ditemukan masalah bahwa guru kurang dalam memberikan penguatan verbal dan nonverbal. Penguatan verbal dan nonvernal dibutuhkan dalam meningkatkan kualitas proses pembelajaran karena dapat meningkatkan rasa percaya diri pada peserta didik. Kualitas proses pembelajaran masuk kriteria Sedang pada siklus ke-1 meningkat menjadi Sangat Baik pada siklus ke-2. Oleh karena indikator keberhasilan penerapan model TPS telah tercapai, maka PTK ini dihentikan.

\section{Motivasi Belajar}

Objek penelitian motivasi belajar adalah kegiatan peserta didik. Saat proses penerapan model TPS, peserta didik lebih bersemangat. Pada kegiatan awal peserta didik diberikan pretest, appersepsi, dan motivasi dengan pertanyaan-pertanyaan menantang.

Pada kegiatan inti, peserta didik diberikan penjelasan tentang proses pembelajaran yang akan dilaksanakan, peserta didik duduk dengan classmate. Setelah peserta didik duduk berpasangan, mereka mendengarkan dan memperhatikan penjelasan pembelajaran kemudian guru memberi pertanyaan-pertanyaan menantang sebagai bahan diskusi. Setelah itu, peserta didik berdiskusi mencari jawaban, mereka saling membagi tugas, saling bertanya jawab, saling berbagi informasi, saling membantu, dan diakhiri mempresentasikan hasil diskusi di depan kelas. Pada kegitan akhir, peserta didik mengerjakan post test dan mengoreksi bersama-sama.

Pengamatan motivasi belajar dilakukan oleh observer dengan cara menyontreng indikator variabel motivasi pada lembar observasi saat proses pembelajaran di dalam kelas, tes siklus ke1 dan siklus ke-2. Observer juga mencatat kejadian selama proses pembelajaran. Hasil pengamatan motivasi belajar dikonversi dengan skala lima dapat dilihat pada tabel 4 .

Tabel 4. Penghitungan Kriteria Motivasi Belajar

\begin{tabular}{lcc}
\hline \multicolumn{1}{c}{ Penghitungan Konversi } & Rentang & Kriteria \\
\hline $89,28+(1,5 \times 6,70)=99$ & 99 ke atas & Sangat \\
& & Tinggi \\
$89,28+(0,5 \times 6,70)=93$ & $93-98$ & Tinggi \\
$89,28-(0,5 \times 6,70)=86$ & $86-92$ & Sedang \\
$89,28-(1,5 \times 6,70)=79$ & $79-85$ & Rendah \\
Di bawah & 78 ke & Sangat \\
$89,28-(1,5 \times 6,70)=79$ & bawah & Rendah \\
\hline
\end{tabular}

Pada siklus ke-1 terdapat dua peserta didik yang memiliki motivasi belajar Sangat Rendah, atas temuan tersebut guru dan observer melakukan refleksi, kemudian guru memanggil peserta didik dan memberikan nasehat dan bimbingan pentingnya perilaku disiplin dalam kegiatan pembelajaran. Setelah peserta didik tersebut mendapat nasehat dan bimbingan dari guru, satu dari dua peserta didik tidak masuk dalam kriteria Sangat Rendah pada siklus ke-2. Pada siklus ke-2 masih ditemukan dua peserta didik yang memiliki motivasi belajar Sangat Rendah. Atas kejadian tersebut guru dan observer 
melakukan refleksi. Kemudian salah satu dari dua peserta didik yang memiliki motivasi Sangat Rendah pada siklus ke- 1 dan siklus ke- 2 diberikan bimbingan oleh BK dan melaporkan kepada wali siswa.

Dari hasil analisa data tentang motivasi belajar diperoleh hasil bahwa motivasi pada siklus ke-1 pada kriteria Sangat Tinggi 9,38\%, Tinggi $34,38 \%$, Sedang $31,25 \%$, kemudian dijumlah dan menghasilkan kriteria Sedang sebesar 75,01\%. Pada siklus ke-2 pada kriteria Sangat Tinggi 28,13\%, Tinggi 37,50\%, Sedang $25 \%$, kemudian dijumlah dan menghasilkan kriteria Sedang sebesar 90,63\%. Peningkatan motivasi belajar dari siklus ke-1 menuju siklus ke2 dapat dilihat pada tabel 5 berikut.

Tabel 5. Motivasi Belajar

\begin{tabular}{lcccc}
\hline \multirow{2}{*}{ Kriteria } & \multicolumn{2}{c}{ Siklus ke-1 } & \multicolumn{2}{c}{ Siklus ke-2 } \\
\cline { 2 - 5 } & $\mathrm{f}$ & $\%$ & $\mathrm{f}$ & $\%$ \\
\hline Sangat Tinggi & 3 & 9,38 & 9 & 28,13 \\
Tinggi & 11 & 34,38 & 12 & 37,50 \\
Sedang & 10 & 31,25 & 8 & 25,00 \\
Rendah & 6 & 18,75 & 1 & 3,25 \\
Sangat Rendah & 2 & 6,25 & 2 & 6,25 \\
\hline \multicolumn{1}{c}{ Jumlah } & 32 & 100 & 32 & 100 \\
Rata-rata & \multicolumn{2}{c}{89,28} & \multicolumn{2}{c}{92,15} \\
$\quad$ SD & \multicolumn{2}{c}{6,70} & & 7,03 \\
\hline
\end{tabular}

Mengacu pada indikator keberhasilan PTK bahwa motivasi belajar peserta didik pada kriteria Sedang minimal $75 \%$ pada siklus ke-1 dan siklus ke-2, dan oleh karena indikator motivasi belajar telah tercapai, maka PTK ini dihentikan.

\section{Aktivitas Belajar}

Obyek penelitian aktivitas belajar adalah kegiatan peserta didik. Pada saat proses pembelajaran dengan menerapkan model TPS, peserta didik tampak lebih banyak beraktivitas. Pada kegiatan awal, peserta didik menjawab salam dari guru, merespon apperspsi dan motivasi dari guru. Pada kegiatan inti, peserta didik dudk berdampingan dengan classmate, mendengarkan dan memperhatikan materi pembelajaran, menirukan pelafalan, bertanya jawab dengan guru, bertanya jawab dengan classmate, berdiskusi dengan classmate, mempresentasikan hasil diskusi, memperbaiki hasil diskusi. Pada kegiatan akhir, peserta didik mengerjakan post test dan mengoreksi bersamasama, mendengarkan dan memperhatikan rencana pembelajaran pertemuan akan datang, menjawab salam penutup.

Pengamatan aktivitas belajar dilakukan oleh observer dengan cara menyontreng indikator variabel aktivitas belajar pada lembar observasi pada saat proses pembelajaran dan tes siklus ke1 dan siklus ke-2. Observer juga mencatat kejadian selama proses pembelajaran. Hasil pengamatan aktivitas belajar dikonversi dengan skala lima dapat dilihat pada tabel 6 .

Tabel 6. Penghitungan Kriteria Aktivitas Belajar

\begin{tabular}{lcc}
\hline Penghitungan Konversi & Rentang & Kriteria \\
\hline $86,63+(1,5 \times 8,51)=99$ & $99 \mathrm{ke}$ & Sangat \\
& atas & Tinggi \\
$86,63+(0,5 \times 8,61)=91$ & $91-98$ & Tinggi \\
$86,63-(0,5 \times 8,61)=82$ & $81-90$ & Sedang \\
$86,63-(1,5 \times 8,61)=74$ & $74-80$ & Rendah \\
Di bawah & $73 \mathrm{ke}$ & Sangat \\
$86,63-(1,5 \times 8,61)=74$ & bawah & Rendah \\
\hline
\end{tabular}

Pada siklus ke-1 terdapat empat peserta didik yang memiliki aktivitas belajar Sangat Rendah. Guru dan observer melakukan refleksi kemudian guru memanggil peserta didik dengan memberikan nasehat dan bimbingan tentang pentingnya perilaku disiplin dalam aktivitas pembelajaran. Setelah peserta didik mendapat nasehat dan bimbingan dari guru, pada siklus ke2 hanya ditemukan dua peserta didik yang masih memiliki aktivitas belajar Sangat Rendah. Satu dari peserta didik yang memiliki aktivitas belajar Sangat Rendah pada siklus ke-1 dan siklus ke-2 diberikan bimbingan oleh $\mathrm{BK}$ dan melaporkan kepada wali siswa.

Dari hasil analisa data aktivitas belajar diperoleh hasil bahwa aktivitas belajar pada siklus ke-1 pada kriteria Sangat Tinggi $0 \%$, Tinggi $12,50 \%$, Sedang $59,38 \%$, kemudian dijumlah dan menghasilkan kriteria Sedang sebesar 71,88\%. Pada siklus ke-2 pada kriteria Sangat Tinggi $28,13 \%$, Tinggi $28,13 \%$, Sedang 28,13\%, kemudian dijumlah dan menghasilkan kriteria Sedang sebesar $84,39 \%$. Peningkatan motivasi belajar dari siklus ke-1 menuju siklus ke-2 dapat dilihat pada tabel 7.

Tabel 7. Aktivitas Belajar

\begin{tabular}{lcccc}
\hline \multirow{2}{*}{ Kriteria } & \multicolumn{2}{c}{ Siklus ke-1 } & \multicolumn{2}{c}{ Siklus ke-2 } \\
\cline { 2 - 5 } & $\mathrm{f}$ & $\%$ & $\mathrm{f}$ & $\%$ \\
\hline Sangat Tinggi & 0 & 0 & 9 & 28,13 \\
Tinggi & 4 & 12,50 & 9 & 28,13 \\
Sedang & 19 & 59,38 & 9 & 28,13 \\
Rendah & 5 & 15,38 & 3 & 9,38 \\
Sangat Rendah & 4 & 12,50 & 2 & 6,25 \\
\hline \multicolumn{1}{c}{ Jumlah } & 32 & 100 & 32 & 100 \\
Rata-rata & - & 86,63 & - & 92,03 \\
$\quad$ SD & - & 8,51 & - & 7,98 \\
\hline
\end{tabular}

Mengacu pada indikator keberhasilan PTK bahwa aktivitas belajar peserta didik pada kriteria Sedang minimal 75\% pada siklus ke-1 dan siklus ke-2, dan oleh karena indikator 
aktivitas belajar telah tercapai, maka PTK ini dihentikan.

\section{Prestasi Belajar}

Setelah penerapan model TPS dalam pembelajaran siklus ke-1 dan siklus ke-2 selama empat kali pertemuan, kemudian guru melaksanakan tes siklus ke- 1 dan tes siklus ke- 2 untuk mengetahui prestasi belajar Bahasa Arab. Prestasi belajar Bahasa Arab yang dimaksud adalah rata-rata nilai dan jumlah peserta didik yang mencapai KKM 70.

Indikator prestasi belajar Bahasa Arab terdapat peningkatan jumlah ketuntasan belajar Bahasa Arab dari prasiklus menuju siklus ke-1 dan siklus ke-2 minimal 50\%. Penulis menetapkan angka keberhasilan PTK pada variabel prestasi belajar Bahasa Arab sebesar 50\% disebabkan oleh peserta didik yang belum pernah belajar Bahsa Arab sebesar 89,25\%, dan rata-rata pada prasiklus sebesar 4,25 serta jumlah ketuntasan pada prasiklus sebesar 6,25\%.

Dari hasil analisa data prestasi belajar diperoleh hasil bahwa jumlah ketuntasan belajar belajar Bahasa Arab pada prasiklus sebesar 6,25\%, siklus ke-1 sebesar $43,75 \%$ dan pada sikulus ke-2 sebesar 59,37\%. Peningkatan prestasi belajar Bahasa Arab dari siklus ke-1 menuju siklus ke-2 dapat dicermati pada tabel 8 berikut.
Mengacu pada indikator keberhasilan PTK bahwa prestasi belajar belajar Bahasa Arab meningkat minimal $50 \%$ pada siklus ke- 1 dan siklus ke-2, dan oleh karena indikator prestasi belajar Bahasa Arab telah tercapai, maka PTK ini dihentikan.

Penelitian serupa berjudul Penerapan Model Arias pada Pembelajaran Kooperatif Tipe ThinkPair-Share (TPS) dalam Meningkatkan Motivasi Belajar dan Hasil Belajar Siswa Kelas VIII MTs AlAmin Pakis. Penelitian tersebut memperoleh hasil bahwa peningkatan motivasi pada kriteria sangat tinggi $54,8 \%$ pada siklus pertama meningkat $67,8 \%$ pada siklus kedua, terdapat peningkatan sebesar 13\%. Pada kriteria tinggi, dari 45,2\% turun menjadi $32,2 \%$. Penurunan persentase sebesar $13 \%$. Ketuntasan hasil belajar 0\% pada prasiklus, meningkat $48,3 \%$, pada siklus pertama, dan meningkat $83,9 \%$ pada siklus kedua (Kusmawati dan Lestari, 2016). Penelitian tersebut berbeda dengan penelitian yang di lakukan oleh penulis. Penelitian terdahulu tidak menyertakan aktivitas belajar peserta didik sebagai variabel dalam penelitiannya, sementara peneliti menyertakan aktivitas belajar sebagai variabel dalam PTK. Motivasi belajar Bahasa Arab yang tinggi akan meningkatkan aktivitas belajar. Motivasi dan aktivitas belajar Bahasa Arab yang tinggi akan meningkatkan prestasi belajar Bahasa Arab.

Tabel 8. Prestasi Belajar Siklus ke-1 dan Siklus ke-2

\begin{tabular}{lcccccc}
\hline \multirow{2}{*}{ Kriteria } & \multicolumn{2}{c}{ Prasiklus } & \multicolumn{2}{c}{ Siklus ke-1 } & \multicolumn{2}{c}{ Siklus ke-2 } \\
\cline { 2 - 7 } & $\mathrm{f}$ & $\%$ & $\mathrm{f}$ & $\%$ & $\mathrm{f}$ & $\%$ \\
\hline Tuntas & 2 & 6,25 & 14 & 43,75 & 19 & 59,37 \\
Tidak Tuntas & 30 & 93,75 & 18 & 56,25 & 13 & 40,63 \\
\hline Jumlah & 32 & 100 & 32 & 100 & 32 & 100 \\
\hline Jumlah Nilai & 1320 & - & 2162 & - & 2270 & - \\
\hline Rata-rata & 4,25 & - & 69,74 & - & 73,23 & - \\
\hline
\end{tabular}

\section{Simpulan dan Saran}

Dari hasil olah dan analisa data serta pembahasan dapat disimpulkan bahwa pertama penerapan model TPS pada sikuls ke-1 termasuk Sedang dan pada siklus ke-2 Sangat Baik, ini artinya TPS mampu meningkatkan kualitas pembelajaran Bahasa Arab. Kedua TPS mampu meningkatkan motivasi belajar peserta didik. Ketiga TPS mampu meningkatkan aktivitas belajar peserta didik. Keempat TPS mampu meningkatkan prestasi belajar Bahasa Arab.

Berdasarkan kesimpulan di atas, penulis memberikan saran kepada guru Bahasa Arab supaya meningkatkan kualitas proses pembelajaran mealui penerapan TPS. Proses pembelajaran yang berkualitas akan meningkatkan motivasi dan aktivitas serta prestasi belajar Bahasa Arab.

\section{Daftar Pustaka}

Asrori, H I. (2012). Strategi Belajar Bahasa Arab Teori dan Praktik. Malang: Misykat Indonesia.

Djamarah, S B. (2011). Psikologi Belajar. Jakarta: Rineka Cipta.

Djiwandono, S E W. (2008). Psikologi Pendidikan. Jakarta: PT Grasindo.

Hamalik, O. (2008). Proses Belajar Mengajar. Jakarta: PT Bumi Aksara.

Isjoni, H. (2011). Pembelajaran Kooperatif Meningkatkan Kecerdasan Komunikasi Antar Peserta Didik. Yogyakarta: Pustaka Pelajar. 
Iskandarwassid dan Sunendar, D. (2008). Strategi Pembelajaran Bahasa. Bandung: PT Remaja Rosdakarya.

Lestari, A F. (2019). Penerapan Metode Pembelajaran Think Pair Share (TPS) untuk meningkatkan kemampuan menulis Bahasa Arab Siswa - siswi MTs Satu Atap Al Hidayah Batu, Pembelajaran Bahasa, Sastra, dan Budaya Arab di Indonesi, Seminar Nasional Bahasa Arab Mahasiswa III HMJ Jurusan Sastra Arab Fakultas Sastra Universitas Negeri Malang, hal. 250-259.

Lie, A. (2008). Cooperative Learning: Memperaktekkan Cooperative Learning di Ruang-Ruang Kelas. Jakarta: PT Grasindo.

Mahmudah, U dan Rosyidi, A B. (2008). Active Learning dalam Pembelajaran Bahasa Arab, Malang: UIN Malang Press.

Porter, B D dan Hernnack, M. (2008). Quantum Learning: Unleashing the Genius In You, Diterjemahkan Oleh Alwiyah Abdurrahman. Bandung: PT Mizan.

Rochimah, D C dan Hanif, M dan Dina, L N A B. (2019). Penerapan Model Pembelajaran Kooperatif Tipe Think Pair Share untuk Meningkatkan Kemampuan Menghafal Mufrodat Bahasa Arab Pada Siswa Kelas III di Madrasah Ibtidaiyah Islamiyah Kota Malang, JPMI: Jurnal Pendidikan Madrasah Ibtidaiyah, 1(2), 74-81.

Slamento. (2003). Belajar dan Faktor-Faktor yang Mempengaruhinya. Jakarta: RenikCipta.

Slavin, R E. (2015). Cooperative Learning Teori, Riset dan Praktik. Diterjemahkan Oleh Narulita Yusro. Bandung: Nusa Media.
Sudijono, A. (2008). Pengantar Evaluasi Pendidikan. Jakarta: PT Rajagrafindo Persada.

Sugiarto, D dan Sumarsono, P. (2014). The Implementation of Think-Pair-Share Model to Improve Student's Ability in Reading Narrative Texts, International Journal of English and Education, 3(3), 206-216.

Sugiyono. (2015). Metode Penelitian Tindakan Komprehensif (Untuk Perbaikan Kinerja dan Pengembangan Ilmu Tindakan). Bandung: Alfa Beta.

Suhrowardi. (2020). Improving Writing Skills; an Implementation of "Think Pair Share" For Islamic Junior Schools Students. JOLLT Journal of Languages and Language Teaching. 8(3), 287-296.

Suprijono, A. (2012). Cooperative Learning Teori \& Aplikasi PAIKEM. Yogyakarta: Pustaka Pelajar.

Suyitno. (2018). Metodologi Penelitian Tindakan Kelas Eksperimen dan $R$ \& D. Bandung: Alfa Beta.

Syah, M. (2011). Psikologi Pendidikan Dengan Pendekatan Baru. Bandung: PT Remaja Rosdakarya.

Widoyoko, S E P. (2014). Penilaian Hasil Pembelajaran di Sekolah. Yogyakarta: Pustaka Pelajar.

Peraturan Menteri pendidikan dan Kebudayaan Nomor 23 Tahun 2016 tentang Standar Penilaian Pendidikan.

Peraturan Akademik MTs Negeri 1 Bantul Tahun Pelajaran 2019/2020). (KKM MTs Negeri 1 Bantul Tahun Pelajaran 2019/2020). 